NGOs clash

\section{at side-show}

\section{meeting}

The main idea behind the nongovernmental organisation's (NGO) forum, according to its organiser Dr Karim Ahmed, is to bring together the many different types of NGO with an interest in science and technology for development especially those "bored" lobbying delegates at UNCSTD. What he regards as most important, however, is not how the forum is conducted but what happens after it. "If we do not have a plan to follow the conference, all our efforts will have been a complete failure", he told the opening session last week.

Just what should be achieved and how, however, were points of fierce disagreement throughout the first week. Some NGOs, critical that the forum had no plans for making a direct impact on the main UNCSTD meeting, argued that it should prepare a statement for UNCSTD. But during discussions early on in the week, that idea was dismissed by suggestions from the organisers that the preparation of such a statement would be a waste of time and that the NGOs with consultative status can lobby UNCSTD anyway.

As a result of those discussions together with criticisms that there was no room within the forum programme for discussion of the two background napers prepared in advance - it was agreed to devote brief daily meetings and one whole day session to trying to formulate a 'plan of action' for the NGOs after the conference. The plan of action should come up with something "at least in terms of mechanisms", said Ahmed. One idea might be a clearing-house or secretariat for managing and channelling funds.

Agreeing on a firm plan, though, is bound to be difficult because of the diversity of the NGO group. There are basically three types of NGO, says Ahmed: those representing the professional interests of scientists, mainly from developed countries, those representing development groups often working at the village level in developing countries, and those which are politically active in issues such as environment and disarmament who want to impress on the Third World the dangers of "non-benign" technology. "What do these three groups have in common? They have rather diverse interests," says Ahmed.

The group mainly representing the professional interests of first world scientists has already broken away from the rest. Before the start of the forum, the Group of 19 , which was formed last year and issued a 'declaration' at the Singapore Symposium, announced the setting up of a

\title{
Organiser criticised but not bowed
}

\section{Ziauddin Sardar profiles Dr Karim Ahmed, chairman of the forum for non-governmental organisations}

Next to Joao Frank da Costa, the Secretary-General of UNCSTD, Dr Karim Ahmed, the chairman of the NGO forum is probably the most hard working man in Vienna this week. While da Costa has received a considerable amount of attention, little is known about Ahmed who, after all, has just as great a responsibility.

Ahmed, a Pakistani ex-patriate, who became a naturalised American citizen last year, describes himself now as a "typical middle class American", He traces his background to Japan, where his father, originally from Bombay, was an import-export merchant. He married a local girl, and just before the Second World War broke out, took his wife and children to Shanghai where they spent four years. In 1945, the family moved to India, and after the partition to Karachi.

In Karachi, Ahmed's father was responsible for setting up Habib Textile Mills, one of the major textile mills of Pakistan. Ahmed confesses that "the mill does not belong to the family any more" But he is "'well off", and the standing of his family in Pakistan is on a par with Adamjee, Dawud and other textile industrialists. In religious affiliation he belongs to the Memons, a pious and strong group of Sunni Muslims.

Ahmed did not follow his father into

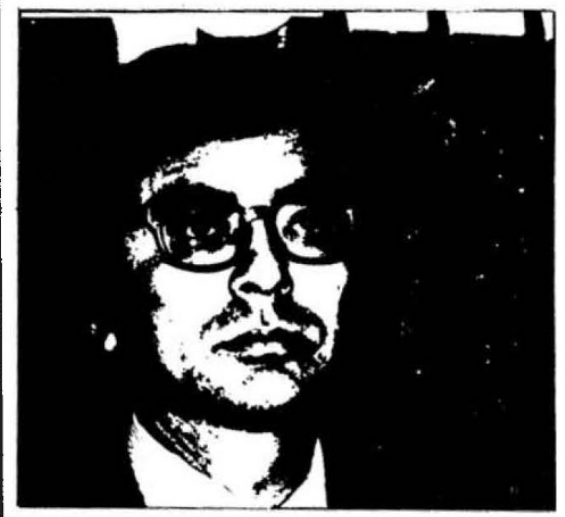

Ahmed: interested in mobilising people.

new body with the aim of implementing the principles emerging from UNCSTD. The new body is to be based on the International Council of Scientific Unions (ICSU) and will seek funds from UN agencies for specific projects. Its precise nature is to be decided on by a preparatory meeting sometime this week.

Many of the other types of NGO view the Group of 19 with suspicion, seeing it as an elitist organisation made up of scientists who ask how theil knowledge can be applied to development rather than taking the developing country approach of asking what are the problems first.

The main discussion at the NGO forum, the textile industry. "My interests were more academic", he says. He graduated from the University of Karachi and then decided to pursue his higher studies in the United States. After obtaining a masters in chemistry from the University of Minnesota, he moved to Harvard where he was awarded a doctorate in biochemistry in 1969.

During his student years, Ahmed developed a keen interest in radical issues. He worked for years as a volunteer for black organisations, and during the mid-sixties with Ralph Nader's public interest research group.

"I have always been conscious of social aspects of science and technology", he says. His first major research project was a lead-poison screening programme which assessed the potential impact of lead poisoning on the black community. Ahmed says proudly that "it lead to many city ordances". He now spends most of his time investigating the environmental impact of technology as a research director of the Natural Resources Defense Council, a cooperative venture between lawyers and scientists.

Ahmed's involvement with the UN began only two years ago. "I have always been interested in mobilising people" he says. He saw the NGO forum as a challenge and "went out" for its chairmanship.

There has however been considerable criticism of Ahmed's handling of the forum. He accepts the criticism as "symbolic", saying "there are some people who must criticise", and considers that most of it is based on a misunderstanding of the role of the NGO forum. "We are not a counterconference to UNCSTD", he says. "Neither are we a political group. The purpose of the forum is to allow as many NGOs as possible to meet and discuss the important issues". But he hopes that some of them will organise joint ventures and carry them out after the conference. $\square$

during the first week however, did not centre on the politics of formulating concrete proposals for action. Attempts were made to discuss some of the more pragmatic problems of development such as the role of energy and environment policy and the arms race in development. But even this part of the proceedings has gone badly. Many delegates have criticised the organisation of the conference which does not allow useful debate. If the NGOs are to bring pressure on governments then they should be using the forum to thrash out specific proposals and identify areas for special attention, they argue.

Judy Redfearn 